\title{
Domestic Violence and Psychological Oppression In Alice Walker's The Color Purple
}

\author{
C.G. Karthikadevi, R. Kannan
}

\begin{abstract}
African-American literature is otherwise known as slave narratives. The popular African-American writers are Langston Hughes, Richard Wright, Toni Morrison, Zora Neale Hurston, Frederick Douglass, Alice Walker etc. The Color Purple is a well-known epistolary novel written by Alice Walker in 1983. The novel brought her a Pulitzer Prize and National Book Award in 1983. This is a novel about a young fourteen year old black girl. She is tortured physically, emotionally, sexually by her step father and her husband. Later on she develops an intimate relationship with Shug. It has changed her life topsy-turvy. The poor, ugly, innocent, oppressed, inferior woman tremendously changed as a woman of self confident, beautiful and proud human being.
\end{abstract}

Keywords: Violence, Suffering, Racism, Sexism, Psychological Oppression, Female Relationship, Self-Discovery.

\section{INTRODUCTION}

In The Colour Purple there is physical as well as psychological oppression and violence experienced by the main character named Celie. The female characters are struggling with both gender and racial oppression in the novel. Even though she is experiencing heavy miserable condition in her life, there is a great extent of personal strength, fighting spirit and courage possessed by the main character. Because of the physical and psychological oppression, Celie cannot come up in her life. Celie is under the clutches of domestic violence. As a woman she has a lot of field to achieve in the external society. This paper also explains about the ill treatment of her step father and husband. Celie and Shug Avery involve a lesbian relationship. Their relationship leads Celie to feel emotionally and sexually satisfied. She finds Shug as a remedy to all her tortures and sufferings. She is also able to find a true identity and gain strength to lead a peaceful and independent life.

\section{THE ANIMALISTIC NATURE OF STEP FATHER}

The Color Purple is about the role of male domination. It

Revised Manuscript Received on December 24, 2019.

C.G.Karthikadevi Department of English, Part time Research Scholar in Kalasalingam University, Krishnankovil. Email: cgkarthikadevi@gmail.com.

Dr. R.Kannan, Associate Professor, Department of English, Kalasalingam Academy of Research and Education. Email: kannanraman1975@gmail.com also depicts about the frustration of Black woman's struggle for independence. Celie is an uneducated black who lived in the village of Georgia. Celie writes so many letters to God to whom she can share her utmost pain. She could not express all her sufferings to the world. She doesn't have the heart to reveal her innermost pain to the pretentious and disloyal human beings. She lived a life of prisoned bird. She could get relief from all her pain and bottled up emotions only by writing letters to reveal the private issues to God. She endured a lot of pain in her life from her childhood days itself. When she was very young, her stepfather impregnated her and her two children were born and sold. Without having a human compassion, he sold the boy child also. She was crying a lot. She couldn't take any decision in the male chauvinistic society. When he finds that her breasts running down milk, "Why don't you look decent"? She is always considered as an ugly Celie. Continuously she is experiencing torture from her step father. "He beat me today cause he say I winked at a boy in church. I may have got something in my eye but I didn't wink" [7]. Celie also tells that she never look into the eyes of any man. She tells that is the plain truth. Celie's mother becomes seriously ill. At that time also without having any human concern like an animal, he compels her to have sexual intercourse with him. Finally she died. Alphonso brings a new wife to his home but he continues to abuse Celie, the victim of the novel. If a man died in the patriarchal society, what is the state of a woman? Can she marry anyone like Alphonso did? If Celie's mother had any illegal relationship with anyone, what is the name given to her by the society? What are the physical and mental tortures given to her by the man in the society? A woman is just a woman. She has to undergo all sorts of pain physically and psychologically. She cannot raise her voice. But a man can live as he wishes to live and wander. No one can question him. Is this the justice or equality that we have got in the name of independence? Like an animal Alphonso treats both his wife and Celie. Only Animals have the nature of hunting and killing. It also gets immense pleasure by inflicting pain to other animals. The state of Celie is also very pathetic. How can a father do such a merciless attitude to a daughter?. In this world, whom can Celie believe? How can a man get pleasure by hurting and giving pain to others? It is so cruel. Only animalistic nature of human beings can do such a heartless and merciless way of ill treatment.

\section{THE ILL TREATMENT OF CELIE'S HUSBAND}

$\mathrm{Mr} \_$wants to marry the pretty and young sister Nettie. Alphonso does not allow to get married with Nettie. Instead of that he prefers that $\mathrm{Mr}$ _ should marry the ugly Celie. 
He also accepts the ugly Celie as a bride. He marries her without intention or willingness. That is why Celie's heavenly joyful dreamy married life also turned into hellish, cruel, painful life. Her dreams go vanished and shattered into pieces. He also ill treats her. The patriarchal society itself recognises the attitude of an ill-treating husband. Whatever happens to a woman under the domestic circle, she has to keep mum. Or else the blessed wedding ceremony vow will be broken by her husband. The innocent suppressed woman will get lost of their precious life. Throughout their life they have to lead the life of isolation and pathetic helpless state. The following lines express the statement or role of a husband according to $\mathrm{Mr}$ daddy why he beat me. $\mathrm{Mr}$ point of view. "Harpo ast his say, Cause she my wife" [23]. As a submissive lady Celie obeys and accepts both her Pa and husband's ill treatment. They both consider her as an ugly and worthless person. She accepts their judgement and ill-treating and also endured all sufferings with patience which a modern or present society woman cannot accept. She feels numb, unfeeling state of emotional life. Even though, she survives in the world with a hope. In the moment of extreme pain, she considers herself as a tree. Basically tree is considered as a symbol of tolerance. The following lines express the agony and consolation of Celie. "I make myself wood. I say to myself, Celie, you a tree. That's how come I know trees fear man." [23]. Mr__ still desires Nettie and when he takes an advantage of her, she flees away for her own safety. $\mathrm{Mr}$ _ also fallen in love with a woman named Shug Avery, a sultry singer. He gets pleasure in many ways. But he didn't give up maltreating Celie. He expects her to obey in all ways. He hides all those letters sent by Nettie to Celie. Thus he plays the role of distancing the sisterhood relationship. Celie is isolated and longing for a friendly relationship to whom she can share her private issues.

\section{IV.THE INTIMATE RELATIONSHIP OF CELIE AND SHUG AVERY}

The suppressed Celie is longing for a lovable close relationship. When Shug is not feeling well, $\mathrm{Mr}$ _ brings her to home. Celie takes utmost care of her. The following lines express their close relationship. "She come over and hug me a long time. Us two married ladies now, she say Two married ladies, And hungry, she say. What us got to eat?" [100] .Celie reveals her humiliation and dejection to Shug. She also finds a real compassionate towards Shug. Celie's tears wipe out by Shug. "She start kissing the water as it come down side my face" [103]. She also expresses agony and yearning for love to Shug. "Nobody ever love me, I say. She say, I love you, Miss Celie. And then she haul off and kiss me on the mouth um, she say, like she surprise. I kiss her back, say, um too" [103]. Shug also enquires about Celie's dearest lovable sister. They share a lot of information about what they like most in the world. Shug spends her precious time to listen the cherishing moments that has happened in the life of Celie.Celie also get inspired and talking to her naked self in the mirror by recollecting the memories of Shug. Celie is wondering whether Shug has fallen in love with her short hair or her dark skin. She also mentions that her nose is just a nose. Her lips just lips. There is nothing special in the body of Celie to fall in love. They involve in lesbian relationship also. She could realize in Shug - motherly love, fatherly caring, sisterhood, friendly attitude, love of her lost child, quenching the thirst for sex.Celie herself revealed her intention. When she gets a chance to sleep with Shug, she feels like a heaven. She could get the love of motherhood. Sleeping with Nettie also didn't satisfy her that much. Sleeping with $\mathrm{Mr}$ _ also didn't feel that much pleasure at all. In her mind, she is leading a life of virgin. Shug plays her role as a mother of Celie. With the help of Shug, Celie finds her own self identity. Shug acts as an antidote to Celie's domestic abuse and giving her both the opportunity to discover her own individual strengths.

\section{CONCLUSION}

The paper brings out the agony and abuse of the main character Celie. She has taught a lesson to the womankind in the society. Even in an imbalanced situation also how a woman should come up in her life. The woman has the power to achieve anything in the world. She could make steps with the stones that have thrown on her by the domestic circle and the society. The problems faced by Celie make her a woman of emotional maturity and self independent. Even though she considers as a worthless person by her step father and husband, she proves that she is indeed a valuable and precious character in the novel.

\section{REFERENCE}

1. Walker, Allice. The Color Purple. United States Of America : Harcourt Brace Jovanovich. 1983

\section{AUTHORS PROFILE}

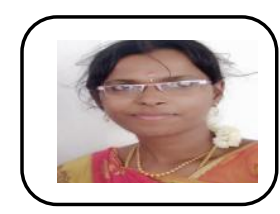

c.g. karthikadevi, research scholar, department of english, kalasalingam academy of research and education.

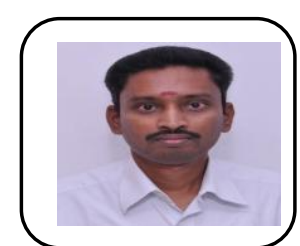

Dr.R.Kannan is an Associate Professor of English in Kalasalingam Academy of Research and Education. He completed his Ph.D. in 2009. He has a teaching experience of over fourteen years. Under his guidance, one awarded his Doctorate, fourteen scholars completed their M.Phil dissertation. At present, under his supervision, four scholars are pursuing their Ph.D. He has published two papers in Scopus Indexed Journal, fourteen papers in UGC listed and other journals and also presented papers in both National and International conferences. He was a Doctoral Committee Member in VIT, Vellore. He is the journal reviewer of Humanities, Online International Journal, Switzerland. He is the BEC Centre Exams Manager and Speaking Examiner for BEC in Kalasalingam Academy of Research and Education. 